\title{
APRESIASI ESTETIKA DAN ETNIS MULTIKULTUR DI INDONESIA: MENCEGAH DISHARMONI, MENJAGA KEBERTAHANAN NKRI
}

\author{
Ketut Sumadi \\ Jurusan Pedalangan, Fakultas Seni Pertunjukan, \\ Institut Seni Indonesia Denpasar, Indonesia
}

\begin{abstract}
The goal of this article is to reinforce the existence of the Republic of Indonesia (NKRI), by promoting a multicultural awareness and essential understanding of national diversity or heterogeneity. Every sort of culture and the living method stand in the same level. Therefore, there is no more cultural superiority and cultural inferiority. Attempt to appreciate every single ethnic art throughout the country must be a priority in keeping the existence of the ethnicity and appreciating the local culture. However, this racial protection must not create exclusive attitude that trivializes or undermines other tribal culture. Every single tradition or tribal culture in Indonesia has its own distinctive meaning and relevant value that contribute toward solving problems of the local people.
\end{abstract}

Keywords: Multikultural, kesenian, and kesatuan.

Indonesia termasuk negara besar di kawasan Asia Tenggara yang terdiri atas ratusan pulau, memiliki beragam etnik (suku) yang hidup dan berkembang dengan tradisi serta keyakinan religius yang unik sehingga lahir corak budaya berbeda satu sama lain. Kemajemukan budaya atau multibudaya dalam pandangan Posmodernisme dikenal dengan istilah multikulturalisme. Paham multikulturalisme diperkirakan diwacanakan pertama kali pada tahun 1960 oleh ahli Sosiologi Kanada, Charles Hobart ketika dilangsungkannya konferensi tentang Dewan Kanada tentang agama Kristen dan Yesus di Winnipeg (Manitoba) Kanada, namun sebagai wacana politik yang resmi berkembang di Kanada tahun 1997 dan di Australia tahun 19771978 (Ardhana,2001:3), konsep multikulturalisme ini diterjemahkan Edi Sedyawati sebagai konsep "aneka budaya" (Bagus, 2001:8).

Keunikan dan keanekaragaman kultur masing-masing etnis itu, baik dalam bentuk seni sastra, seni pertunjukkan, seni suara/musik, seni kriya, maupun seni lukis, memiliki estetika yang berbeda pula.. Di Eropa 
perumusan tentang estetika baru terjadi tahun 1648 oleh Baumgarten, tetapi baru dapat diakui secara umum setelah Immanuel Kant (1724-1804), seorang Filsuf Jerman, memakainya dalam tulisan-tulisan falsafinya (Jelantik, 1994: 15). Estetika sebagai filsafat keindahan memang berkaitan erat dengan seni (Wurianto, 2006 dalam Suastika, 2006:vii). Mengutif Plato (dalam Sutrisno, 1999;107), Wurianto menguraikan, keindahan dapat ditengarai dari dua hal, yaitu benda-benda/hal-hal indah merupakan kelompok objek yang dilihat, dinikmati dan didengar yang berada di sekeliling manusia. Selain itu keindahan ada tanpa melekat dalam dunia objek-objek indera, tetapi berada dalam "the intelligible world", yaitu dunia nontemporal, nonspesial, tetapi dalam dunia forma yang berisi sari-sari pokok dan abadi dari pengetahuan. Keindahan mengatasi dunia indera, pengalaman, yaitu pengalaman akan keindahan merupakan hal yang khusus, tidak dapat tuntas dideskripsikan, dipaparkan. Sementara itu, Thomas Aquinas memberikan syarat-syarat mengenai keindahan dengan ciri: (a) Indah itu sekaligus sempurna, tidak terpecah dan tidak tersamai; (b) Berciri harmoni, selaras, bermakna proporsional; (c) Jelas, terang, dan jernih. Sedangkan G.W.F. Hegel (dalam Woryomartono, 2001:39) menyatakan bahwa letak dan kedudukan karya seni yang dalam hal ini disebut dengan "fina art" adalah usaha dan manifestasi dari manusia untuk membawa keindahan alam raya ke dalam ranah budaya.

Dalam perspektif kajian budaya (culture study) di Indonesia, masingmasing kultur etnis di Indonesia memiliki estetika yang sarat muatan untuk membangun kehidupan harmonis dan selaras dalam ranah budaya Nusantara yang bhineka tunggal ika. Karena itu, tidak berlebihan kiranya, jika kajian pengetahuan tentang estetika dan etnis multikultur di Indonesia diharapkan dapat mengangkat nilai relevansi dan makna dari keragaman budaya tersebut, sehingga akan melahirkan pemahaman tentang seni budaya sebagai upaya mencegah disharmoni berbangsa dan bernegara, yang pada akhirnya bermuara pada kebertahanan Negara Kesatuan Republik Indonesia (NKRI).

Di sinilah diperlukan adanya kemauan yang tulus dari seluruh etnis di Indonesia untuk melangkah seiring seirama dalam mengapresiasi estetika dalam kandungan budaya yang beragam itu. Konsep apresiasi sangat dekat dengan penikmatan. Dalam apresiasi terdapat proses yang melibatkan aspek pemahaman, sikap, dan penilaian Pemahaman terkait dengan pengalaman pribadi yang berhubungan dengan ingatan, penerapan, analisis, kemampuan mensintesis dan unsur-unsur kritis. Di tengah gegap gempitanya kreativitas para seniman melahirkan karya-karya seni, menurut Jelantik (1994:7), pembicaraan tentang estetika menjadi semakin penting, karena karya seni yang dilahirkan itu tidak bisa lepas dari rasa kepedulian atas bobot dan mutu estetik, serta kepedulian atas arah kemana dibawanya kesenian itu. Oleh karena itu, wahana yang besar untuk menumbuhkan iklim apresiasi 
estetika itu adalah melalui bangku pendidikan, baik formal maupun nonformal.

Secara formal pengenalan dan kajian apresiasi estetika diberikan di sekolah dari tingkat Taman Kanak-kanak sampai di Perguruan Tinggi, terlebih pada Perguruan Tinggi Seni seperti di Institut Seni Indonesia (ISI) di seluruh Indonesia, kajian estetika tidak cukup di atas kertas semata, tetapi lebih pada usaha membawa keindahan itu dalam ranah budaya yang mengantar setiap orang menemukan jati dirinya dan kesadaran sebagai warga negara Indonesia yang bersatu serta berdaulat.

Sedangkan secara nonformal, pengenalan dan kajian apresiasi estetika kultural multietnis di Indonesia bisa diberikan lewat aktivitas berkesenian di bale banjar atau di sanggar-sanggar kesenian yang kini tumbuh subur di tengah masyarakat, seperti yang dilakukan Sanggar Tari "Lokananta" dari Banjar Mukti Singapadu, Sukawati Gianyar (Bali Post, 4 Februari 2007). Pesta Kesenian Bali (PKB) juga bisa menjadi studi kasus menarik, karena selama sebulan berlangsungnya PKB setiap tahun, banyak menampilkan seniman dari berbagai etnis di Indonesia, bahkan dari luar negeri. Demikian pula para seniman kini mulai menampilkan karya-karya seni yang menggabungkan berbagai elemen budaya etnis di Indonesia sebagai wujud usaha mereka membangun semangat kebersamaan dan persatuan bangsa melalui estetika.

Tulisan singkat ini memang dimaksudkan untuk menggugah apresiasi masyarakat terhadap estetika seni multietnis itu dari perspektif kajian budaya dalam rangka mencegah disharmoni dan menjaga kebertahanan NKRI di tengah krisis multidimensi yang, salah satunya diwarnai dengan terjadinya konflik etnis di beberapa daerah di Indonesia, sampai saat ini.

\section{TEORI ETNIS DAN MEMBANGUN RUANG APRESIASI ESTETIKA}

Theories of Ethnicity atau Teori Etnik (Schefold, 1998:259), menggariskan bahwa keberadaan etnis-etnis di dunia memiliki perjalanan sejarah yang panjang berkaitan dengan penjajahan. Etnis-etnis di negara kawasan Asia Tenggara termasuk Indonesia yang merupakan negara bekas dijajah misalnya, dalam perjalanan sejarah, keberadaan etnik yang beragam itu pada zaman penjajahan sering dijadikan isu dan alat untuk memecah belah persatuan. Politik kolonial yang terkenal dengan istilah politik memecah belah atau politik adu domba merupakan senjata ampuh untuk menaklukkan etnis yang memberontak kepada penjajah. (Koentjaraninggrat 1993:3 dalam Schefold, 1998:259-260). Boleh jadi, pemahaman estetika sengaja disumbat agar terjadi pengaburan atau pemusnahan ciri-ciri harmoni, selaras dan kebersamaan dalam estetika.. 
Setelah zaman kolonial, keberadaan etnik di seluruh dunia, termasuk di Indonesia memang tidak lagi berurusan dengan penjajah, tetapi justru masalah muncul kerena tekanan politik penguasa, ekonomi dan pengaruh modernisasi/globalisasi yang merangsek dengan teknologi canggih. Mengutif pendapat Glazer dan Moynihan (1963), Clifford Geertz (1973), Schefold menyatakan bahwa masalah etnik secara psikologis menjadi sangat kuat mempengaruhi seseorang karena munculnya kesadaran akan persamaan asal-usul, tempat kelahiran, bahasa, dan pandangan hidup. Munculnya kesadaran etnik ini di mata para penguasa secara politis bisa dimanfaatkan sebagai kekuatan untuk menekan sikap primodial dan dijadikan wahana pemersatu dalam proses modernisasi, serta meningkatkan kualitas hubungan sosial. Di Negara-negara Dunia ke-Tiga, termasuk Indonesia, kesadaran menumbuhkan sikap solideritas antar etnik yang berbeda ini terus dipelihara demi memperkukuh persatuan nasional. Seperti pendapat Geertz, keunggulan domestik dari etnik harus mampu memberi kontribusi terhadap negara, bukan sebaliknya malah menimbulkan sikap primordial berlebihan.

Kelemahan sikap primordial adalah adanya anggapan sifat otomatis, di mana primordialisme dalam perkembanganya tidak hanya menyangkut orang tertentu, tetapi menyangkut identitas suatu masyarakat yang sangat cepat terbentuk melalui suatu persahabatan yang sering tidak disadari. Oleh karena itu, sikap primodial menunjukkan kecintaan terhadap etnik lebih bersifat eksklusif. Sekalipun demikian, dalam perkembangan dunia menjadi "desa global", di mana kebudayaan dunia berbasis pada canggihnya teknologi komunikasi massa lintas negara tanpa batas sehingga keberadaan etnik semakin kabur. Namun ikatan emosional etnik yang kuat masih bertahan dalam hubungan kekeluargaan meskipun dalam tataran yang lebih simpel dan bentuk baru yang dipercaya memiliki makna mendalam untuk membangun kesejahteraan hidup mereka. Karena itu, memang perlu adanya penelitian yang lebih komprehensif tentang keberadaan etnik untuk merespon dan mengaktualisasikan nilai-nilai kehidupan yang dimiliki, sehingga di antara aneka ragam etnik itu dapat menumbuhkan rasa saling menyayangi dan menghindari terjadinya konflik.

Setiap etnik seharusnya tidak tampil atau mengelompokan diri secara eksklusif. Mengutif pendapat Liddle (1970:16), Schefold menyatakan, dalam kaitannya dengan kompleksitas hubungan antar negara, keragaman etnik dengan budaya yang berbeda bisa menjadi kekuatan sosial. Perbedaan agama atau pandangan hidup misalnya, menjadi ikatan etnik yang kuat dan mempengaruhi suatu negara secara nasional. Karena itulah, dalam era global saat ini, perlu digalang sikap loyalitas dan menjaga hubungan harmonis antar etnik. Terlebih di kawasan Asia Tenggara yang multietnik dan memiliki struktur yang kuat, sehingga setiap negara semestinya mendukung keberadaan etnik tersebut untuk menjaga keutuhan negara itu sendiri. 
Sebaliknya, setiap etnik juga harus aktif dan berpartisipasi penuh membangun sikap nasionalisme.

Belajar dari perjalanan sejarah itu, semestinya kini dibuka ruang-ruang yang luas dan pemerintah memberikan fasilitas yang memadai untuk membangun apresiasi estetika etnis multikultural, sehingga bisa ditarik jalinan benang merah guna menghindarkan Bangsa Indonesia dari krisis dan konflik antar etnis.

\section{INDONESIA, NEGARA MULTIETNIS DI ERA GLOBAL}

Giddens (2001: 8), menyatakan bahwa etnis-etnis di dunia, termasuk Indonesia, dengan kebudayaannya masing-masing memperoleh momentum untuk bangkit pada era global. Kebijakan penerapan Otonomi Daerah (UU No. 32/2004) sebagai respon terhadap globalisasi memberi angin segar bagi tumbuhnya rasa percaya diri etnis di berbagai daerah di Indonesia.

Penerapan Otonomi Daerah tersebut, seperti diingatkan Giddens, juga mengindikasikan bahwa globalisasi tidak hanya berkaitan dengan sistem-sistem besar, seperti tatanan keuangan dunia. Globalisasi bukan sekadar soal apa yang terjadi di "luar sana", terpisah dan jauh dari orang per orang, tetapi juga merupakan fenomena "di sini", yang mempengaruhi aspek-aspek kehidupan kita yang intim dan pribadi dari masing-masing etnis.

Apa yang disampaikan oleh Giddens tersebut tampaknya sudah terbaca jauh sebelumnya oleh raja-raja di Nusantara dan para pendiri Bangsa Indonesia sebelum memproklamirkan kemerdekaan Negara Kesatuan Republik Indonesia. Nilai-nilai luhur dari pandangan hidup, tradisi, atau budaya masing-masing etnis di Nusantara dijadikan dasar negara dan undang-undang dasar negara. Pancasila dan Undang-Undang Dasar 1945 merupakan wujud dari nilai luhur tersebut dan sebagai tali pengikat seluruh etnis menjadi Bangsa Indonesia. Pancasila merupakan ideologi negara yang memuat kebudayaan normatif yang ideal, terkait dengan sistem berpikir, sistem kepercayaan, dan praktek-praktek simbolik yang bertalian dengan tindakan sosial dan politik (Atmaja:2006). Jiwa kebangsaan terus dibangun oleh tokoh-tokoh Bangsa Indonesia seperti dirangkum oleh Maya Safira Muchtar (2005) dalam bukunya "Tiga Generasi Satu Visi. Dialog Kebangsaan Lintas Zaman Bersama Sastrawan Achdiat K. Mihardja dan Spiritualis Anand Krishna”. Di antara banyak ungkapan tokoh yang dikutif, salah satu pernyataan Sukarno patut direnungkan dalam membangun bangsa yang kuat di atas beragam etnis, sebagai berikut:

"Apakah yang mengikat manusia itu menjadi satu jiwa? Kalau menurut Ernest Renan, yang menjadi pengikat itu ialah kehendak untuk hidup bersama ....... artinya kehendak supaya berkumpul bersama. Jadi gerombolan manusia meskipun agamanya berwarna 
macam-macam, meskipun bahasanya bermacam-macam, meskipun asal turunannya bermacam-macam, asal gerombolan manusia itu mempunyai kehendak untuk hidup bersama, itu adalah bangsa"

Ungkapan Sukarno tersebut memang bisa menjadi peringatan dini terhadap munculnya resiko mayarakat multietnis di era global, di mana adanya kecenderungan dominasi satu kebudayaan di atas kebudayaan yang lainya, dalam konteks pemahaman budaya mayoritas dan minoritas antar etnis. Titik-titik persinggungan budaya antaretnis memiliki peluang besar untuk menjadi konflik etnis, karena sebagian besar konflik antaretnis yang terjadi bermula dari munculnya rasa ketidakpuasan yang dialami oleh kelompok masyarakat etnis minoritas atas perlakuan kelompok mayoritas dalam negara yang terdiri dari kelompok masyarakat yang majemuk (Perwita, 1996:150).

Pemberlakuan UU RI No. 22/1999 Jo UU RI No 32/2004 memberikan peluang yang besar bagi kemultikulturan di Indonesia. Dengan penerapan UU ini diharapkan dapat mengantar masyarakat ke dalam suasana rukun, damai, egaliter, saling menghargai, saling menghormati, tanpa ada konflik dan kekerasan tanpa mesti meghilangkan kompleksitas perbedaan yang ada. Akan tetapi pemberian ruang gerak bagi kemultikulturan pada era reformasi yang ditandai dengan otonomi daerah, ternyata menimbulkan masalah, karena yang muncul pada masa otonomi adalah perlombaan untuk menciptakan kebijakan yang dalam perspektif pluralisme menjadi paradoksal ( Gunawan, 2005:xi dalam Atmaja:2006). Hal ini terlihat dari munculnya nasionalisme kesukubangsaan (etnonasionalisme) seperti Gerakan Aceh Merdeka, Gerakan Papua Merdeka. Begitu pula hubungan antaretnik pada suatu ruang yang semula damai, tiba-tiba berkonflik seperti di Poso, Ambon, atau di Kalimantan. Bisa juga dicermati kasus-kasus "adat" di Bali, seperti terjadi konflik antar desa pakraman atau banjar yang memperebutkan tapal batas desa, rebutan setra dan pura.

Konflik etnis mudah terjadi apabila tidak ada perasaan saling menghormati keberadaan budaya etnis masing-masing. Para provokator dengan mudah merancang taktik adudomba untuk memecah belah persatuan bangsa melalui sentimen egois etnis. Muchtar (2005: 43), menyatakan bahwa rencana yang matang, canggih, dan teratur untuk memecah belah Bangsa Indonesia terus berlangsung. Beberapa kekuatan dari luar, baik perorangan maupun yang disponsori oleh negara secara langsung maupun tidak langsung, sedang bekerja untuk memecah belah bangsa Indonesia. Di antaranya Kelompok Bin Ladin yang jelas-jelas memiliki kaki tangan di negeri kita. Kelompok ini memiliki hubungan dengan beberapa oknum dari Kerajaan Saudi yang ingin menguasai kepulauan kita. Lagi-lagi budaya asing dan agama dijadikan alat untuk mencapai tujuan mereka itu. 


\section{APRESIASI ESTETIKA ETNIS MULTIKULTUR: STUDI KASUS SANGGAR TARI LOKANANTA, SINGAPADU}

Keanekaragaman kebudayaan Indonesia yang didukung oleh 931 etnik, 600-an bahasa daerah dan ribuan aspirasi kultural (Mulyana, 2005 : 9), maka dalam proses interaksi sebagai bagian dari negara kesatuan antar etnik tersebut diperlukan sebuah toleransi yang tinggi terhadap keberadaan kebudayaan satu etnis dengan etnis yang lainnya dalam kerangka nasionalisme kebangsaan, sebuah ideologi transetnis yang menjadi cita-cita bersama. Toleransi inilah yang nantinya bermuara pada konsep adaptasi budaya sebagai sebuah out put yang bijaksana dan bebas konflik.

Konsep adaptasi sangat berkaitan dengan persoalan lingkungan sebagai kunci dalam orientasi ekologi budaya. Adaptasi sering diartikan sebagai proses yang menghubungkan sistem budaya dengan lingkungannya. Mustahil berpikir tentang adaptasi tanpa mengacu pada sesuatu lingkungan tertentu (Kaplan,1999:112). Dalam masyarakat multietnik maka kecenderungan proses adaptasi budaya ini semakin tinggi, sebab mobilitas penduduk antaretnis sangat tinggi. Konsep adaptasi ini adalah sebuah proses penyesuaian suatu budaya terhadap budaya lainnya, dalam rentang waktu yang cukup panjang.

Pada tahap pertama atau struggle for life terjadi persaingan untuk membentuk jatidiri di antara budaya yang beranekaragam, pada tahap berikutnya keungulan merupakan kekuatan (power) untuk menentukan kebertahanan budaya bersangkutan dalam menghadapi tantangan (the survival of the fittest). Bagi budaya yang tidak mampu mempertahankan diri atau lemah akan lenyap dengan sendirinya seiring dengan perjalanan sang waktu (natural selection), Jika mampu melewati seleksi alam ini, maka hasil dari proses seleksi alamiah ini akan dapat menunjukan hasil yaitu sebuah kemajuan (progress). Barangkali ini dapat dikatakan sebagai hakikat dari adaptasi budaya sebuah masyarakat, yang prosesnya memerlukan waktu yang cukup panjang dan bertahap (evolution).

Adaptasi budaya antaretnis di Indonesia, saat ini mengharuskan kita untuk melihat perspektif kemajemukan dan adaptasi tersebut dalam konteks daerah atau lokal, nasional dan internasional atau lintas negara. Kemajemukan dan adaptasi antaretnis pada tingkat lokal pada umumnya terdapat di daerah perkotaan, khsususnya kota-kota besar. Kemajemukan ini disebabkan oleh terpusatnya kegiatan ekonomi, politik, industri terutama industri berteknologi tinggi, pusat kekuasaan/pemerintahan dan sebagainya. Sebagai konsekuensi dari tersentralisasinya segala kegiatan seperti itu, maka jumlah urbanisasi menjadi sangat tinggi dan sulit untuk membendungnya di samping itu kota juga merupakan tempat berbagai hal yang saling bertentangan (kontras). Kota merupakan pusat pendidikan, seni, ilmu pengetahuan dan pengobatan, kegembiraan, daya tarik dan "kemajuan"; 
sebaliknya daerah pedesaan dipandang sebagai tempat cara pandang kedaerahan, takhayul, kebodohan dan kefanatikan (Horton dan Chester L. Hunt, 1989:151 dalam Dwija, 2007: 20).

Meningkatnya jumlah urban ke kota, baik dari satu etnis ke wilayah kota etnis lain, maupun berasal dari etnis yang sama, menyebabkan di wilayah atau kota yang bersangkutan berkumpul berbagai etnis dengan kebudayaannya sendiri-sendiri. Satu contoh kota Jakarta sebagai Ibukota Negara, atau Kota Denpasar sebagai ibukota Provinsi Bali, hampir seluruh etnis yang ada di Indonesia terwakili keberadaannya di Jakarta atau Denpasar ini. Di Jakarta atau Denpasar telah berdiri berbagai peguyuban etnis yang berusaha mengembangkan kebudayaannya melalui solidaritas keetnisannya. Kemajemukan budaya seperti ini memang bagaikan pisau bermata dua, di satu sisi akan mampu menjadi alat perekat persatuan dan kesatuan bangsa, lewat adaptasinya, meskipun tidak sepenuhnya mampu meleburkan diri dalam budaya lokal di daerah bersangkutan, sedangkan di sisi lain merupakan sumber konflik yang laten, jika konsep multikulturalisme tidak sesuai dengan proporsinya.

Fenomena ini seirama dengan fenomena tahun 1980-an di mana lembaga-lembaga pengkajian atau studi etnismekultural, seperti Javanologi, Sundanologi, Baliologi, dan lain-lain tumbuh subur dengan berbagai aktivitasnya. Namun justru pada saat itu muncul tundingan dan kontroversi yang cukup meresahkan. Pihak yang bersebrangan menganggap pemekaran aktivitas etnisme kultural memungkinkan tumbuhnya ideologi etnisme yang sempit dan berbahaya ( Mulyana, 2005:8).

Dalam upaya memperkuat keberadaan Negara Kesatuan Republik Indonesia (NKRI), maka kesadaran multikulturalisme harus ditumbuhkan dengan membuka pemahaman dasar tentang sisi heterogenitas bangsa, bahwa segala macam budaya dan cara hidup adalah sama derajatnya. Dengan demikian, tidak ada lagi budaya lebih tinggi (superiority) dan budaya lebih rendah (inferiority).

Pemikiran posmodernisme, yang memberi perhatian dan menghargai kearifan lokal, maka banyak harapan yang ditumpukan kepada pemahaman tentang prinsip multikultural (Ardika: 2006) untuk bisa mengantar bangsa Indonesia keluar dari berbagai krisis, baik yang menyangkut ideologi, politik, sosial, ekonomi, lingkungan, agama maupun kebudayaan itu sendiri. Pasal 32 Undang - Undang Dasar (UUD) 1945 juga menyatakan: "Negara memajukan kebudayaan nasional Indonesia di tengah peradaban dunia dengan menjamin kebebasan masyarakat dalam memelihara dan mengembangkan nilai-nilai budayanya". Presiden Susilo Bambang Yudhoyono (2006) pun menegaskan, bahwa kebudayaan merupakan bagian mendasar dari kehidupan setiap orang dan setiap kelompok masyarakat. Deklarasi UNESCO tentang Culturl Diversity (Keragaman Budaya-red) memberi rumusan bahwa keragaman kebudayaan merupakan bagian integral 
dari hak asasi manusia. Karena itu, pembangunan yang diarahkan untuk pertumbuhan dan pemuliaan martabat manusia haruslah memiliki dimensi kebudayaan.

Semboyan Bhineka Tunggal Ika dalam Pancasila, lambang Negara Indonesia, tidak bisa terbantahkan keampuhannya mengukuhkan Negara Kesatuan Republik Indonesia (NKRI). Budayawan Muji Sutrisno dan Taufik Rahzen dalam Dialog Budaya (Metro TV: 2006) yang selalu menjadikan Bali sebagai contoh studi kasus dalam pembicaraannya tentang multiculture dan culture studies. Muji Sutrisno misalnya, menyebut konsep kearifan lokal desa, kala, patra dari Bali sebagai konsep tentang tempat, ruang dan waktu, bisa sejalan dengan pemikiran culture studies yang melahirkan sikap saling menghargai keragaman budaya dan mengembangkan sikap toleransi untuk saling memahami makna budaya masing-masing daerah. Selain itu, orang Bali juga memiliki beberapa konsep untuk menjalin hidup bersama, saling menghormati, dan menghargai satu sama lain, seperti tat twam asi, menyama braya, sagilik saguluk salunglung sabayantaka, paras paros sarpanaya.

Taufik Rahzen lebih berani menyebut Bali sebagai model tempat persemaian budaya global tanpa menggilas budaya lokal. Pendapatnya ini didasari atas hasil pengamatannya tentang teguhnya masyarakat Bali mempertahankan tradisi seperti ritual yang hampir tiada putus-putusnya. Disamping mengutif hasil penelitian orang asing yang mengadakan penelitian di tiga tempat yakni New York, Papua, dan Bali, dalam kaitannya dengan teroris dan tragedi bom di Bali Oktober 2002. Ternyata, dibanding New York dan Papua, masyarakat Bali memiliki respons budaya yang sangat unik untuk bangkit dari tragedi, yakni bangkit dengan kearifan lokalnya, dalam bentuk ritual, perenungan ke dalam diri dan tidak balas dendam. Sedangkan masyarakat New York dan Papua lebih memilih membela diri dengan balas dendam lewat invasi perang. Ini terlihat dari invasi militer Amerika dan sekutunya ke negara-negara yang diduga sebagai sarang teroris, sedangkan di Papua terjadi perang suku.

Kasus menarik patut dilirik aktivitas Sanggar Tari Lokananta di Banjar Mukti Singapadu, Sukawati, Gianyar yang berdiri tahun 2001. Jumlah anak-anak yang belajar menari di sanggar ini tercatat 180 orang, namun yang aktif bisa mengikuti pelatihan setiap minggu dua kali yakni pada hari Jumat dan Minggu sore sekitar 100 orang. Yang tidak aktif karena banyak ikut kegiatan di sekolah, tapi jika mereka akan pentas atau ngayah menari, biasanya mereka minta jadwal berlatih secara khusus.

Di Sanggar Tari Lokananta ternyata tidak hanya diberikan pelatihan menari Bali, tetapi juga diberikan pelatihan tari-tarian etnis dari berbagai daerah di Nusantara. Menurut Ketua Sanggar Tari Lokananta, I Wayan Sutirtha, SSn, apresiasi seni etnis multikultur itu diberikan kepada anak-anak agar mereka lebih mengenal seni budaya yang beranekaragam di Indonesia. 
"Kami sejak dini ingin menanamkan semangat multikulturalisme, semangat saling menghormati dan menghargai seni budaya berbagai daerah di Tanah Air, sebagai ilmpelementasi dari konsep "Ajeg Bali" dan memperteguh Negara Kesatuan Republik Indonesia," ungkap Sutirtha yang juga dosen ISI Denpasar ini. (Bali Post, 4 Februari 2007).

Kondisi bangsa yang memprihatinkan ini memang telah menjadi wacana hangat belakangan ini. Banyak orang, para seniman termasuk Wayan Sutirtha, tergerak melakukan sesuatu untuk menyelematkan bangsa dengan cara dan kemampuannya masing-masing. Sebagai seniman tari yang telah beberapa kali mengantar Kabupaten Gianyar meraih juara satu dalam bidang tari kreasi pada Pesta Kesenian Bali, I Wayan Sutirtha kini mengajak anak-anak yang tergabung di Sanggar Tari Lokananta mencintai kebudayaan bangsanya melalui seni tari. "Kekayaan budaya Nusantara itu harus dikuasai oleh anak-anak kita, agar mereka menjadi insan yang mampu hidup penuh toleransi dan saling menghormati, menembus batas etnis serta lapisan sosial," katanya.

Namun untuk menumbuhkan semangat multikulturalisme dan memahami budaya orang lain di kalangan anak-anak melalui kegiatan berkesenian, memang tidak mudah. "Diperlukan kesabaran dan ketekunan melatih mereka, karena olah tubuh dalam gerakan tarian itu masih asing, di samping itu mereka belum memahami nilai-nilai luhur yang ada dalam tarian itu," ungkap Sutirtha serius. Syukurnya, anak-anak memiliki talenta seni yang bagus, sehingga gerakan tarian akhirnya bisa dikuasai meskipun kurang sempurna, seperti penari dewasa.

Dalam tahap awal pengenalan tari Nusantara itu, Wayan Sutirtha yang mendirikan sanggar tari sejak enam tahun yang lalu bersama istrinya, Dwi Wahyuning Kristiansanti, S.Sn, anak-anak diberikan Tari Saman, sebuah tarian dari Daerah Aceh yang gerakannya sangat dinamis dengan suasana ceria. "Tarian ini sangaja dipilih, sekaligus kita ingin mengajak anak-anak memberi dukungan semangat dan moral kepada anak-anak di Aceh yang ditimpa bencana gempa dan tsunami," ungkap Sutirtha. Di samping itu, anak-anak dilatih Tari Rantak, sebuah tarian daerah Minangkabau, Sumatera Barat. Tarian ini mendapat inspirasi dari gerakan Pencaksilat yang tangkas, cekatan, dan penuh sukaria, sehingga cocok bagi perkembangan dan jiwa anak-anak gemar bermain dan periang. "Untuk melatih dua tarian ini perlu waktu cukup panjang, agar mereka tidak hanya hafal gerakannya, tetapi juga memahami budaya Aceh dan Minangkabau untuk menambah pengetahuan budaya yang mereka dapatkan di bangku sekolah," ujar Sutirtha, ayah dua putra ini.

Tari Saman dari Daerah Aceh, dan Tari Rantak dari daerah Minangkabau, Sumatera Barat, yang dipersembahkan pada puncak perayaan Hari Ulang Tahun Sanggar Tari Lokananta ke-6, tanggal 28 Januari 2007, di samping tari Bali berupa Tari Kukus Arum dan Tari Cak Sunda-Upasunda, 
merupakan salah satu wujud dari proses belajar anak-anak yang panjang dalam mengapresiasi estetika etnis multikultur di Indonesia. Karena itu, tema yang diusung pada peringatan pada Hut ke -6 Sanggar Tari Lokananta itu yaitu "Dengan Semangat Multikultural, Kita Bersatu dalam Aktivitas Seni Budaya Menuju Ajeg Bali dan Keutuhan NKRI “. Tema ini kedengarannya memang sangat bombastis, tetapi dalam perspektif kajian budaya, kita patut memberikan dukungan dan semangat, bahwa Sutirtha dan anak didiknya telah berbuat yang terbaik demi bangsa dan negara. Meski belum berjalan sempurna, proses belajar apresiasi estetika model Sanggar Tari Lokananta ini patut ditiru dan disebarluaskan.

\section{MENCEGAH DISHARMONI DAN MEMPERKUAT KEBERTAHANAN NKRI}

Fenomena yang diungkap oleh Safira Muchtar dan kasus Sanggar Tari Lokananta menggelitik untuk dicermati secara mendalam dikaitkan dengan pemahaman teori etnik yang dikemukakan oleh Schefold. Perlu kejelian melihat bagaimana reaksi dan kreasi masyarakat dalam kemajemukan budaya, sehingga persinggungan budaya etnis ini tidak mengarah pada bentuk konflik etnis, tetapi menuju sebuah "peleburan" yang berbentuk adaptasi dan mencegah disharmoni dalam hubungan antaretnis. Pemahaman estetika kultural dalam hal ini menjadi sangat penting, karena menurut Geria (1997: 55), kesenian bisa berfungsi sebagai media diplomasi. Potensipotensi kunci yang dimiliki kesenian sehingga dapat berperan sebagai media diplomasi adalah: (1) Kesenian memiliki variasi dan keanekaragaman yang besar; (2) Memiliki wujud yang kongkret dan mudah mengkhalayak; (3) Mudah menggugah apresiasi dan menumbuhkan sikap saling menghormati dan saling menghargai; (4) Memiliki dasar-dasar estetika yang asasi dan dapat merupakan bahasa universal yang mampu menembus berbagai batas dan perbedaan geografis, politik, ras, ideology, sehingga efektif sebagai media komunikasi dan diplomasi.

Dalam konteks mencegah disharmoni dan memperkuat kebertahanan NKRI, fungsi komunikasi dan diplomasi kesenian antar etnis di Indonesia menjadi sangat strategis. Dalam menyikapi disharmoni, menurut Dwija (2007: 15-16), setidak-tidaknya ada dua konsep yang perlu mendapat perhatian mendalam, karena kedua konsep tersebut dapat menimbulkan konsekuensi yang berbeda jika tidak dijelaskan secara dialektik. Kedua konsep itu adalah masalah kemajemukan budaya atau masyarakat dan adaptasi budaya antaretnis. Meskipun kedua konsep ini tampaknya memiliki makna yang berbeda, namun korelasinya bersifat dialektik, artinya kedua konsep tersebut bagaikan dua sisi mata uang, sehingga diperlukan pemahaman yang utuh. 
Masyarakat tidak dapat dibayangkan tanpa kebudayaan, dan sebaliknya, kebudayaan hanya relevan karena masyarakat yang menciptakannya. Masyarakat majemuk dapat dimaknai sebagai jalan memahami kemajemukan kebudayaan masyarakat Inidonesia, yang memang dari segi geografis telah membentuk lapis-lapis budaya secara horizontal. Faktor geografis ini merupakan salah satu pembentuk struktur masyarakat Indonesia sebagai sebuah sistem kemasyarakatan dan kebudayaan nasional. Struktur masyarakat Indonesia ditandai oleh dua cirinya yang bersifat unik. Secara horizontal, ia ditandai oleh kenyataan adanya kesatuan-kesatuan sosial berdasarkan perbedaan-perbedaan suku bangsa, agama, adat istiadat, kedaerahan. Secara vertikal struktur masyarakat Indonesia ditandai oleh adanya perbedaan-perbedaan vertikal antara lapisan atas dan lapisan bawah yang cukup tajam. Perbedaan suku bangsa, agama, adat dan kedaerahan seringkali disebut sebagai ciri masyarakat Indonesia yang bersifat majemuk, suatu istilah yang mula-mula diperkenalkan oleh Furnivall untuk menggambarkan masyarakat Indonesia pada masa Hindia Belanda (Nasikun,1995:28). Masyarakat Indonesia dan kompleks kebudayaannya masing-masing adalah plural (jamak) dan sekaligus juga heterogen (aneka ragam). Pluralitas sebagai kontraposisi dari singularitas mengindikasikan adanya suatu situasi yang terdiri dari kejamakan dan bukan ketunggalan, artinya dalam masyarakat Indonesia dapat dijumpai berbagai sub kelompok masyarakat yang tidak bisa disatukelompokkan satu dengan yang lainnya. Masing-masing subkelompok masyarakat itu berserta kebudayaannya bisa sungguh-sungguh berbeda satu dari yang lainnya.

Young dalam bukunya The Politics of Cultural Pluralism (1979) sebagaimana dikutip Usman Pelly dan Asih Menanti (1994:94 dalam Dwija: 2007), memberikan definisi oprasional mengenai masyarakat atau kebudayaan majemuk yang terdiri dari tiga komponen dasar yaitu: (1) Kemajemukan berkaitan dengan suatu kekuasaan atau pemerintahan yang menguasai suatu teritorial tertentu yang mengatur atau memberikan batasbatas wilayah yang jelas terhadap masing-masing kelompok masyarakatnya, di mana mereka dapat melakukan interaksi satu sama lainnya; (2) Dua atau lebih kumpulan (agregasi) masyarakat yang secara kultural dapat dibedakan baik dari sistem budaya maupun politik yang masing-masing mereka miliki. Perbedaan ini dapat diidentifikasi oleh orang lain atau aktor (anggota masyarakat itu sendiri). Perbedaan tersebut merupakan faktor yang berpengaruh dalam kehidupan masyarakat secara keseluruhan terutama dalam kompetisi, interaksi dan konflik yang terjadi dalam berbagai bentuk transaksi dalam pemerintahan ; (3) Dasar solidaritas pengelompokan adalah kebersamaan komunal, atau perkawinan/persaudaraan antaretnis, bahasa kesatuan, kesamaan ras, kasta, kesatuan hubungan darah yang diasumsikan, adat kebiasaan (costum) dan wilayah (teritorial) kenegaraan (state). 
Kemajemukan masyarakat Indonesia telah mengindikasikan adanya kemajemukan budaya, baik pada tataran lokal maupun nasional bahkan gelobal. Dalam masyarakat majemuk sangat sulit mengingkari munculnya kemajemukan budaya, oleh karena masing-masing subkelompok memiliki identitas budaya yang sulit untuk ditunggalkan, meskipun dalam konteks kebudayaan nasional sebagai ciri identitas kebangsaan.

Brian Pay (2002) dalam bukunya "Filsafat Ilmu Sosial Kontemporer" juga memberi pemikiran berdasarkan perspektif multikultural, menjembatani berbagai perbedaan pandangan dan menembus batas-batas dualisme dalam ilmu sosial yang sudah ada. Baginya dalam pendekatan multikultural, ilmu sosial tidak sekedar mengenal, menghargai, dan menyambut perbedaan, tetapi harus terlibat, mempertanyakan, dan mempelajari perbedaan. Untuk memahami orang lain tidak diperlukan kemampuan untuk menyatu secara psikologis pada tahap awal, namun diperlukan kemampuan untuk menginterpretasi makna berbagai macam keadaan, relasi dan proses yang membentuk kehidupan kita. Interpretasi makna membutuhkan adanya suatu kesamaan yang dipahami secara umum dan abstrak antara para penafsir dengan yang ditafsirkan.

Budayawan Muji Sutrisno memandang pemahaman multikultur di Indonesia harus ditingkatkan, karena masing- masing tradisi atau budaya daerah memiliki "makna" dan "nilai relevansi" yang bisa disumbangkan untuk mengatasi masalah yang muncul di tengah masyarakat. "Kekayaan tradisi atau budaya untuk menyelesaikan masalah, bukan untuk menyulut masalah," katanya dalam dialog pagi di stasiun Metro TV, hari Sabtu, 16 September 2006, dengan tema "Tradisi Antara Beban dan Tantangan".

Pandangan Muji Sutrisno ini tampaknya sejalan dengan pendapat Bernard T. Adeney (2000: 7 ), yang mengakui kebudayaan, kelas sosial dan ras mempengaruhi jati diri dan nilai-nilai pribadi seseorang. Ia berusaha memahami mengapa orang dengan latar belakang budaya yang berlainan melihat baik dan buruk secara berbeda. Di sini, seperti pemikiran Brian Pay, perlu ada pemahaman bagaimana kita menanggapi situasi-situasi di mana nilai-nilai kita tidak cocok dengan nilai-nilai kebudayaan lain sehingga tidak terjadi benturan budaya. Adeney kemudian menganjurkan agar dibangun etika sosial lintas budaya agar makna dan nilai budaya yang beragam itu bisa kontekstual dengan perkembangan zaman. Untuk memperkuat pendapatnya, Adeney mengutif pemikiran Charles Taylor yang menyatakan bahwa tindakan-tindakan kultural kita bukan hanya bersifat pribadi atau subyektif, melainkan dibentuk secara sosial. "Tindakantindakan kultural kita bersifat "intersubyektif", artinya kita tidak pernah bertindak sendirian. Makna tindakan kita adalah suatu makna yang dihayati bersama oleh orang lain; makna ini didasarkan pada asumsi-asumsi dan tindakan-tindakan kultural kita. Asumsi-asumsi yang berlainan mengenai bagaimana kebenaran harus dinyatakan oleh seorang yang memiliki 
kebajikan di dalam kehidupan bersama". Selain itu, ia juga sependapat dengan Pierre Casse yang menyatakan bahwa tidak ada kebenaran mutlak, apa yang benar bagi seseorang tidak mesti demikian bagi seorang lainnya. Karena itulah I Wayan Sutirtha dengan Sanggar Tari Lokananta bisa menjadi acuan tepat, betapa panjangnya proses yang harus dilalui untuk mengapresiasi estetika kesenian berbagai etnis, sehingga lewat aktivitas berkesenian bisa ditemukan nilai "kebenaran" yang bisa disumbangkan kepada negara demi mencegah terjadinya disharmoni dalam kehidupan berbangsa dan menjaga kebertahanan NKRI.

Dengan demikian melalui aktivitas apresiasi estetika etnis multikultur yang mendalam, diharapkan tidak muncul rasa ego kedaerahan, tidak ada pemikiran mayoritas dan minoritas; yang ada semestinya "kami bangsa Indonesia", rasa nasionalisme yang kuat.

\section{SIMPULAN}

Pengenalan dan kajian apresiasi estetika diberikan di sekolah dari tingkat Taman Kanak-kanak sampai di Perguruan Tinggi, terlebih pada Perguruan Tinggi Seni seperti di Institut Seni Indonesia (ISI) di seluruh Indonesia. Sedangkan secara nonformal, pengenalan dan kajian apresiasi estetika kultural multietnis di Indonesia bisa diberikan lewat aktivitas berkesenian di bale banjar atau di sanggar-sanggar kesenian yang kini tumbuh subur di tengah masyarakat, seperti yang dilakukan Sanggar Tari "Lokananta" dari Banjar Mukti, Singapadu, Sukawati Gianyar.

Para seniman kini mulai menampilkan karya-karya seni yang menggabungkan berbagai elemen budaya etnis di Indonesia sebagai wujud usaha mereka membangun semangat kebersamaan dan persatuan bangsa melalui estetika. Aktivitas berkesenian di Sanggar Tari Lokananta patut mendapat perhatian, karena I Wayan Sutirtha dan anak didiknya telah berbuat yang terbaik demi bangsa dan negara. Meski belum berjalan sempurna, proses belajar apresiasi estetika model Sanggar Tari Lokananta ini patut ditiru dan disebarluaskan.

Upaya-upaya mengapresiasi etetika kesenian dari berbagai etnis di Tanah Air perlu didorong dalam rangka menjaga eksistensi etnis dan menghargai budaya lokal, namun sikap penjagaan diri itu semestinya tidak melahirkan sikap eksklusif, merendahkan atau mematikan budaya etnis yang lain. Masing- masing tradisi atau budaya etnis di Indonesia memiliki "makna" dan "nilai relevansi" yang bisa disumbangkan untuk mengatasi masalah yang muncul di tengah masyarakat. Kekayaan tradisi atau budaya tersebut untuk menyelesaikan masalah, bukan untuk menyulut disharmoni. Dengan demikian NKRI akan kuat berdiri sepanjang zaman dengan fundasi multikultur. 


\section{DAFTAR RUJUKAN}

Adeney, Bernard T, 2000, Etika Sosial Lintas Budaya, Kanisius, Yogyakarta Ardika, I Wayan, 2006, "Prinsip Multikultural dan Implementasinya", naskah lengkap Materi kuliah Anfulen, Denpasar, Universitas Udayana, 22-29 Agustus.

Atmaja, Nengah Bawa, 2006, "Pemulihan Krisis Kebangsaan dan Multikulturalisme dalam Perspektif Kajian Budaya", makalah pada Seminar Nasional Program Kajian Budaya Universitas Udayana, di Denpasar, 18 Nopember.

Bagus, I Gusti Ngurah, 2001. Reformasi, Multikulturalisme, Dan Masalah Politik Bahasa di Indonesia. Makalah disampaikan pada Kongres Bahasa Jawa III. Yogyakarta: Badan Pekerja Kongres Bahasa Jawa.

Bekker, SJ, JWM, 1984, Filsafat Kebudayaan Sebuah Pengantar, Yogyakarta, Kanisius

Cassirer, Ernst, 1990, Manusia dan Kebudayaan, Sebuah Esei Tentang Manusia, Jakarta, Gramedia

Dwija, I Nengah, 2007, Ideologi dan Politik Kebudayaan d Era Global, Denpasar, Sari Kahyangan

Fay, Brian, 2002, Filsafat Sosial Kontemporer, Yogyakarta, Jendela

Geriya, I Wayan, 1997, "Potensi dan Peranan Kesenian dalam Diplomasi Kebudayaan dan Hubungan Antarbangsa serta Implikasinya Terhadap Pengembangan Kreativitas Seni”, artikel dalam MUDRA Jurnal Seni Budaya, No.5 Tahun V, Maret, Denpasar, STSI.

Giddens, Anthony, 2000, Runaway World, Bagaimana Globalisasi Merombak Kehidupan Kita, Terjemahan Andry Kristiawan S dan Yustina Koen S, Jakarta, Gramedia

Jelantik, A.A.M, 1994, "Peranan Estetika dalam Perkembangan Kesenian Masa Kini”, artikel dalam MUDRA Jurnal Seni Budaya, No.2 Tahun II, Februari, Denpasar, STSI.

Kaplan, David dan Albert A. Manner, 1999, Teori Kebudayaan, Penerjemah Landung Simatupang, Yogyakarta, Pustaka Pelajar

Muchtar, Maya Safira, 2005, Tiga Generasi Satu Visi, Dialog Kebangsaan Lintas Zaman Bersama Sastrawan Achdiat K. Miharja \& Spiritualis Anand Krisna, Yogyakarta, One Earth Media.

Mulyana, 2005, "Identitas Kejawen: Mengurai Benang Kusut", artikel lengkap dalam Kejawen Jurnal Kebudayaan Jawa, Vol.1, No.1, September, Yogyakarta.

Nasikun,1995, Sistem Sosial Indonesia, Jakarta, Grafinso Persada

Parimartha, I Gde, 2006, "Filsafat Kebudayaan Indonesia", naskah lengkap Materi kuliah Anfulen, Denpasar, Universitas Udayana, 22-29 Agustus. 
Perwita, A.A Banyu,1996. "Konflik Antaretnis dalam Masyarakat Global Dan Relevansinya Bagi Indonesia" dalam Analisis CSIS tahun XXV No.2 Maret-April. Jakarta: CSIS.

Rahzen, Taufik , 2006, "Ancaman Globalisasi Terhadap Budaya Lokal", dialog budaya di Metro TV, Jakarta, 7 Oktober, pukul 07.30 Wita.

Redig, I Wayan, 2006, "Filsafat Kebudayaan”, naskah lengkap Materi kuliah Anfulen, Denpasar, Universitas Udayana, 22-29 Agustus

Schefold, Reimar, 1998, "The Domestication of Culture Nation-building and Ethnic Diversity in Indonesia", dalam Globalization, Localization and Indonesia, Editor: Peter J.M.Nas, Leiden, Koninklijk Instituut Voor Taal Land-En Volkenkunde (KITLV) Royal Institute Of Linguistics And Anthropology.

Suastika, I Made, 2006, Estetika Kreativitas Penulisan Sastra dan Nilai Budaya Bali, Denpasar, Program Studi Magister S2 dan S3 Kajian Budaya dan Jurusan Sastra Daerah Fakultas Sastra Universitas Udayana

Sutrisno, Slamet, 2006, "Tradisi Antara Beban dan Tantangan", dialog budaya di Metro TV, Jakarta, 16 September, pukul 07.30 Wita.

Yudhoyono, Susilo Bambang, 2006, Pidato saat Pembukaan Pesta Kesenian Bali XXVIII, 17 Juni 2006 di Denpasar.

. 2007, "Menari Bali, Mencintai Indonesia", berita Bali Post, 4 Februari, hal.1 